\title{
Bearing Material Witness to Musical Sound: Fado's L94 Museum Debut
}

\author{
Kimberly DaCosta Holton
}

\begin{abstract}
Este ensaio analisa a aclamada exposição "Fado: Vozes e Sombras", que teve lugar no Museu Nacional de Etnologia no âmbito da Lisboa 94, e a sua mescla não-ortodoxa de exibição de objectos e material sonoro. Os objectivos deste artigo são duplos. Primeiro, sugiro que ao combinarem multi-sensorialismo com dramaturgia de exposição inovadora, os curadores do MNE desfizeram o paradigma visualista da etnomuseologia, criando uma dinâmica de assistência empenhada, onde os vistantes do museu eram, alternadamente, solicitados aos níveis crítico, emocional e sensorial. Segundo, examino as funções nacionais, do acto de combinar ciência com sensibilidade. Ao integrarem objectos e sons na exposição, os curadores do MNE tentaram "dignificar" o fado através do estudo sistemático e académico. No contexto da Lisboa 94, esta exposição apresentou não apenas o fado enquanto património merecedor da consideração europeia, mas também projectou o discurso antropológico crítico de Portugal para um auditório internacional.
\end{abstract}

\section{MUSEUMS AND SOUND}

In a poem entitled "Apontamentos Tendentes $\dot{A}$ Consecução De Uma Canção de Lisboa" (Notes Toward the Achievement of A Song of Lisbon), musician Sérgio Godinho reflects on the difficulty of capturing music in material form:

How is it possible to write about music? Ethereal entity, palpable only with great effort and imagination, music does not satisfy hunger (as do codcakes), does not quench thirst (as do two glasses of wine), does not replace order or authority (nor would Lisbon want it to), does not negotiate with the reinforced concrete of its commemorative tombstones ... , does not cure illnesses . . Music leaves only a scent in the hand./ And it, I swear to you, is just like basil]. $(1993,29-30)^{1}$

Whether the form is a written poem or the "reinforced concrete of commemorative tombstones," music, Godinho argues, is transposed into "palpable" objects only "with great effort and imagination." Godinho concludes his poem by implying that another sense, the olfactory sense, perhaps relates more easily to music. If anything, he muses, music leaves just a "smell in the hand"-the sweet smell of "basil."

Godinho reveals the key challenge faced by the curators of Lisbon's Museu Nacional de Etnologia (National Ethnology Museum) as they developed a 1994 exhibit devoted to Portugal's most renowned form of popular music, fado. Although sound is one of the primary senses through which we experience our daily worlds, it has historically been excluded from the museum space. Jeremy Silver, of the British Library National Sound Archive, states, "the qualities of stillness and quiet are still largely associated with most kinds of 'serious' learning processes.. ... the invasive quality of the medium which might disrupt the hushed holy atmosphere of the gallery is often cited as the reason not to use sound" in exhibitions $(1990,173)$. According to Silver, curators also eschew the use of 
sound for fear it will distract the viewers, preventing them from "using their own imagination to interpret the artifacts" $(1990,173)$.

Silver analyzes the enforced silence of the museum space in general. By considering the ethnology museum in particular, we can discern a specific ideological rationale for the exclusion of sound. Ethnology museums, historically linked to the discipline of anthropology and the ancillary practice of ethnographic collection, have been spaces dedicated to the display of material objects-objects meant to inform the viewing public about "Other" cultures. ${ }^{2}$ Occularcentrism, the privileging of vision over other senses, characterizes anthropology's disciplinary lineage. Anthropology's visualist empiricism-predicated on methods of observation, data collection, and classification-has in turn, conditioned the practice of ethnographic collection and museum display.

Objects collected by European anthropologists were commonly exhibited in $19^{\text {th }}$ century ethnographic museums either in taxonomic groups or as a part of mini-environments (Dias 1994). Objects either had a formal relationship to other like objects, or to a simulated replica of the indigenous cultural environment. ${ }^{3}$ The museum-goer made sense of other cultures through viewing objects according to these exhibition schema. Ocular cognition was contingent on physical distance from the objects - often held within display cases or behind rope partitions. Sound, which infiltrates physical space creating "much less distance between subject and audience" (Silver 1990, 175), was typically absent from both types of display. Parallel to anthropological methods of observation and collection, learning within the context of the nineteenth-century ethnological museum was achieved primarily through the sense of sight.

The sense of sight is essential to the Western conception of "identity [as] a kind of wealth (of objects, knowledge, memories, experience),"-wealth best communicated through "the accumulation of possessions" (Clifford 1988, 218). In 1994 cultural wealth and identity were key thematics in the exhibition of fado at Lisbon's Museu Nacional de Etnologia (MNE). In 1994 Lisbon became the Cultural Capital of Europe. ${ }^{4}$ Lisbon 94 (L94) constituted Portugal's "cultural debut" following the country's 1986 entry into the European Economic Community as one of its poorest member states. L94 president Vítor Constâncio, clearly articulated the festival's 10 month objective, "Portugal has always been a part of Europe and we seek now to restate our presence and claim greater recognition" $(1994,3)$. L94's blockbuster MNE exhibit, "Fado: Vozes e Sombras" (Fado: Voices and Shadows) comprised an essential part of this claim.

If identity is construed as an "accumulation of possessions," how then, can "immaterial" riches such as musical forms be deployed as "cultural capital," in Bourdieu's sense of the term? ${ }^{5}$ How can the occularcentric prejudices of anthropology and museology be reconciled in an ethnographic exhibit of fado? How can sound, with its 'dangerous' capacity to move, and distract the viewer to the detriment of critical learning, form the cornerstone of an exhibit designed not only to entertain but to instruct (Brito 1994a, Carvalho 1994a)?

A return to Godinho's poem provides some insight into these questions. Music, as Godinho muses, does not "satisfy hunger" as would "codcakes." Music does not "quench thirst" as would "two cups of white wine." Wine and codcakes do, however, function as important markers of fado's social history, material culture, and performance setting. And it is objects such as these which MNE anthropologist-curators used to create their multisensorial exhibition feast.

The goals of the present essay are twofold. Firstly, I will explore how by combining sights and sounds, the MNE exhibit tacked back and forth between the material display of fado's social history and emotive stagings of fado's musical voice. I argue that by combining multi-sensoriality with innovative exhibition dramaturgy, L94 curators disrupted ethnomuseology's visualist paradigm, creating a dynamic of embodied spectatorship, where 
viewers were alternately engaged at critical, emotional and sensual levels. Secondly, I examine the national(ist) functions of blending science and sentience. In assembling exhibit objects and sounds, MNE curators attempted to "dignify" fado through systematic scholarly study. Within the context of Lisbon 94, MNE's exhibit not only showcased fado as national patrimony worthy of European celebration, it also projected Portugal's social scientific voice into the international auditorium of critical anthropological discourse.

\section{SOUNDSCAPES AND ObJeCtS: PRELUde to AN EXHIBIT}

Upon entering the MNE exhibit along a darkened corridor, the museum visitor encounters the first exhibit station, entitled "Preâmbulo e Cidade" (Preamble and City), by walking through a cascading series of urban sounds. We hear the hustle and bustle of Lisbon's historic quarter-pedestrian voices and movements, street vendors cries, wheels of the vendor's pushcart. Continuing along the empty corridor, noises made by people, objects, and activities spill onto one another without visual explication. After entering and exiting "bubbles" of sound, the visitor encounters a wall at the end of the entryway. Several black and white photographs, a historic map of Lisbon, and an exhibition text written in Portuguese and English, await the viewer at the corridor's terminus, like lights at the end of a tunnel.

Illuminated from behind, one of these slender photographs depicts cobblestone steps snaking up toward the viewer. A large archway frames the image from above. At the bottom of the steps a group of women make their way up toward the viewer. They seem momentarily halted by something at the base of the steps that has caught their attention. The liminal space of the archway as threshold beckons the viewer to enter the photographed space of Lisbon in search of a world that seems to promise transformation or, at the very least, passage.

Upon first entering the corridor of sound, I found the material emptiness of the space unsettling. Where were the glass cases? Why were the side walls left blank? Where was I "supposed to be?" Without corresponding objects "illustrating" the recorded sound, I became, in a sense, unmoored. My experience of traditional museum spaces-museums of art, museums of science and industry, regional ethnographic museums-had taught me to wait for visual cues before deciding upon a physical course through the museum space. Museum curators select objects according to organizational themes, and arrange them according to a preconceived exhibition design. The curator uses objects not only to proffer a rhetorical "argument", but also to chart visitors' kinesthetic trajectories. Without material coordinates, the visitor's gaze and companion footsteps are left undirected.

At first I rushed to the end of the space toward the safety of the photographs, map and placards at the end of the corridor. After "reading" both the images and texts, informed and affirmed by the historical and geographical context provided there, I turned back toward the soundscape - concentrating in particular on the timbre of the street vendor's voice and the musicality of his announcement. I realized that without companion images illustrating the products the vendor sells, this "sound bite" became less about commerce and more about cadence. ${ }^{6}$ As the street vendor's voice lilts up and down among phrases, phrases still heard in certain locales throughout $20^{\text {th }}$ century Lisbon, "strawberries for sale" or "hot bread, hot bread," words lose their referentiality. The extended syllables greet the visitor as musical units and lexical units. The Preâmbulo's sparing use of material objects reconditions the museum-goer, forcing him/her to apprehend sound not as decorative background noise, but as the vital focus of cognition, where aural signs must be decifered and remembered.

By combining the photographic images of Lisbon with auditory samples of its social life, the museum-goer is instructed that Lisbon is not only a space of sights but a space of sounds, and that the two sensory faculties must be combined to understand fado. Images 
make noise and noises take on material form. ${ }^{7}$ The synesthetic mixture present in the exhibit's opening station also implies a new kinesthetic role for the museum-goer. The physical space of the museum has been altered, encouraging the visitor to chart new paths in and around spaces sometimes completely devoid of objects. Museum-goers become more aware of their own bodies due to the unorthodox definition and placement of museum "objects." Like de Certeau's notion of "pedestrian speech acts," ambulatory improvisation throughout the museum space constitutes an expressive and perhaps emancipatory act. The Preâmbulo, the "Pre-Ambulation" as it were, prepares museum-goers for a participatory engagement with fado's multi-sensory staging, inviting viewers to navigate the exhibit using divergent kinesthetic mappings.

\section{VOICING FADO’S EARLY HISTORY}

Following the initial "Preâmbulo," "Fado: Vozes e Sombras" unfolds chronologically. MNE curators anchor exhibit temporality to the lives and careers of three famous fadistas, Severa, Alfredo Marceneiro and Amália Rodrigues. "Do Tempo da Severa" (From the Time of Severa), the first of these three stations, features period paintings, drawings and official documents and possessions of Maria Severa Honofriana (1820-1846), the legendary fado vocalist, instrumentalist and lyricist whose life span paralleled fado's first appearance in Lisbon. $^{8}$

The exhibit deployed Severa's life as a chronotope of fado's early history. As a fadista, prostitute and denizen of the poor riverside neighborhood of Mouraria, Severa personified fado in the early to mid 1800 s. Severa's life represented "that fringe of the population with which fado was first associated as it spread throughout the city; prostitution, with all of its social and spatial involvement, spread throughout taverns and brothels among vagrants, pimps and fadistas" (Brito1994c, 19). Severa, the subject of countless poems, plays and songs, was described as "plump, tall, of ample bosom, always adorned with a thick gold necklace and enormous earrings" (Costa 1939, 8). Severa used both her "extravagant" beauty (Sucena 1992) and winsome voice to enchant a wide array of male suitors. Her famous love affair with the Count of Vimioso, a bohemian aristocrat, typified the selective intermingling between social classes of the period. ${ }^{9}$ Severa's identity as a poor prostitute with a penchant for singing ballads to men from varied walks of life typified key elements in fado's initial socio-historical setting.

The first image in "Do Tempo da Severa" invites the museum visitor to peer through yet another photographed archway-this time opening onto Severa's small ramshackle house in the Pátio do Carrasco where she lived with her mother. Drying laundry, crumbling plaster and overturned flowerpots frame the small wooden door Severa used to enter her modest dwelling. Backdrop to her infamous life of song and sexual transgression, Severa's house, street and neighborhood, have become what Gaston Bachelard (1994) terms "eulogized space" - topos immortalized within both the history of fado lyrics ${ }^{10}$ and the MNE exhibit itself. Fado was born in the mouth of a vocalist who lived in a certain house, on a certain street, in a certain neighborhood, among certain people. Representing fado's inception with an image of Severa's childhood home coarticulates personal biography and musical history. History, in this station, is organized around vocality. And Severa, the legendary agent of fado's vocal expression, defines geographical space, historical time and musical genre. In Júlio Dantes' play Severa, for example, the title character proclaims, "A Mouraria, sou eu! O fado, sou eu!" (I am Mouraria! I am fado!) (cited in Sucena 1992, 20). In Fado: Vozes e Sombras, the mythic figure of Severa personifies early fado place and practice.

Further into the station, MNE curators expose both the material and immaterial realities of fado's early vocalizations-grounding the abstract myth of Severa through the nitty gritty 
of personal effects and socio-historical documentation-both visual and aural. ${ }^{11}$ The exhibit moves left to right along a row of glass cases enclosing period paintings, Severa's official Death Certificate, Burial Registry, and hanging above, two of Severa's guitars. Bending down to examine the documents' particulars, we learn that Severa died, an unmarried "meretriz" (prostitute), at the age of 26 . While processing the biographical details revealed on the frayed paper-profession, address, time of death, date of burial - the visitor is confronted with a series of sounds. Women's undulating voices rise and fall, as talk is broken up by laughter, shouts, and whispers. Catty giggles and high-pitched tittering drive the soundscape, until a $19^{\text {th }}$ century brothel in Mouraria seems to materialize out of thin air.

Within this aural context, Severa's nondescript guitars hanging in antiseptic glass cases take on new meaning. Sound dramatizes objects by imbuing them with the suggestion of stories or scenes. Listening to laughter while gazing at guitars and inspecting a prostitute's death certificate forces a narrative connection-one of the laughing women stroking the neck of the guitar, singing a rugged sailor to distraction dies before her time. Sound spills back toward the memory of Severa's tiny photographed door, providing a narrative link between objects artificially amputated from their historical moment and social context. Did Severa enter through this door late at night past the drying laundry and terra cotta pots, guitar on her back, suitor on her arm, whispering so as not to wake the neighbors, erupting into laughter, like the recorded laughter, as she fumbled with her key?

Material fragments isolated for museum display - death certificate, door, pots, laundry, guitar,- constitute what Barbara Kirshenblatt-Gimblett calls "objects of ethnography." She states,

the artfulness of the ethnographic object is an art of excision ... Where does the object begin and where does it end? ... Like the ruin, the ethnographic fragment is informed by a poetics of detachment. Detachment refers not only to the physical act of producing fragments, but also to the detached attitude that makes the fragmentation and its appreciation possible" $(1991,388)$.

If curators select and "excise" objects of ethnography for museum display, it is incumbent upon the visitor to reassemble these fragments into coherence through critical reflection and cognition. Kirshenblatt-Gimblett argues that a poetics of detachment guides not only the curatorial process but the spectatorial process as well. ${ }^{12}$ If, as this paper argues, sound collapses the "detached" distance required for critical viewership, how then do objects of ethnography become differently reassembled through the use of auditory soundscapes?

I would argue that sound, as it was deployed in the MNE exhibit, functions as both a narrative cohesive and a dramatizing agent. In both the "Preâmbulo" and "Do Tempo da Severa" sound was used to conjure both geographical space and social interchange. The soundscapes went beyond the presentation of ambient sound by including the voices of social actors - the street vendors' voices in Lisbon's historic district, and the prostitutes' voices in Mouraria. By conjuring setting as well as sociability, recorded sound dramatized fragmented artifacts into a full-blown mise-en-scène. Ethnographic objects cohere into dramaturgical relationships much like components of a theatrical production on stage. Through the strategic intersection of sights and sounds, MNE curators presented an amalgam of dramatic elements - dialogue, scene, props, sound cues, entrances, exits-to create a multi-sensory depiction of historical time and social space. Visitors were asked not to comprehend an Other culture, as was the historical purpose of the ethnographic exhibit, but to suspend disbelief and enter a scene, as is the purpose of mainstream Western theater.

The use of ambient sound and the recorded voices of actors position objects in a diachronic dialogue with one another, inviting the visitor to consider both historic and contemporary scenes of dramatic production. Contrary to the fears of many curators, 
therefore, the use of sound does not "prevent viewers from using their own imagination to interpret the artifacts," it accomplishes the very opposite. By assembling the piecemeal presentation of "detached" objects, ambient sound and recorded vocality, visitors are able to imagine for themselves several different scenes across a diachronic continuum; the tension between fado's past and present emerges in the artifice of recorded sound as a postproduction medium. Museum curators played with this inherent anachrony to disrupt the overriding context of the ethnographic museum. Fado is represented not as an ossified artifact from a distant chapter of Portugal's past, but as an expressive form in motion, sounding its way into the present moment of embodied viewership.

\section{AMPLIFYING FADO's NATIONAL Voice}

By framing the heated debate concerning fado's musicological lineage within the section "Do Tempo da Severa," the exhibit situated fado within a distinctly Portuguese temporal trajectory. As a featured event in Lisbon 94 programming, the fado exhibit helped demarcate the contours of Portugal's cultural patrimony. The EU's City of Culture Programme was conceived as a vehicle to "bring the member-states closer together . . by celebrating richness born of diversity" (Official Journal of the European Communities 1985). Portugal's more specific aim, however, was to create a high quality festival of domestic culture which would, in the words of L94 Vítor Constâncio, "restate" Portugal's Europeanism. This "restatement" required artful articulations of a territorial nature. Paradoxically, in order to voice its Europeanism, Portugal had to assemble an arsenal of distinctly Portuguese cultural products. "Becoming closer" to other European nations meant roping off and showcasing a national cultural heritage worthy of international celebration.

As noted Portuguese philosopher Eduardo Lourenco explains, historical habit complicates this act of national delineation,

From early on, Portugal's future consisted of the "outside," remoteness, be it ours or that of others. It consisted of India, Brazil, Africa as well as more recently and to varying degrees, Europe. Now is the first time that Portugal and the Portuguese people have had to design, conceive, invent, and give themselves a future, drawing on themselves. $(1998,25)^{13}$

As the ex-libris of the L94 festival, ${ }^{14}$ fado was an essential element in these future designs. Image \#3, entitled "O Marujo" (The Sailor), a 1857 watercolor by E.J. Maia, portrays an African man wearing a sailor's shirt and gold earring while playing a guitarra portuguesafado's signature instrument. The identity of the painting's central figure, a sailor, fadista and an African, implies two primary discursive vectors concerning fado's origins. One body of literature, comprised by fado lyrics, Portuguese poetry and early musicology, muses impressionistically on fado's maritime birth. The well-known lyrics of "Fado Português" explain:

\footnotetext{
O Fado nasceu um dia quando o vento não bulia e o céu o mar prolongava. na amurada dum veleiro no peito dum marinheiro que estando triste cantava que estando triste cantava.
}

[Fado was born one day 
when the wind barely stirred

and the sky extended the sea

on the gunwhale of a boat

in the chest of a sailor

who full of sorrow sang

who full of sorrow sang.]

Turn-of-the-century musicologist Pinto de Carvalho elaborates along the same lines,

For us fado has a maritime origin, an origin that can be discerned by the undulating rhythms like the sonorous movement of the waves .... crashing into the bow, like the gasp of the great blue sea ... sad like the laments of the Atlantic convulsed with silver drool, longing with indefinable nostalgia for an absent country (1984 [1903], 42).

This romantic view of fado's origins underscores Portugal's maritime identity where the fishing industry, colonial navigations and immigration loom large in the historical imaginary. Saudade, the uniquely Portuguese concept of longing and nostalgia for an absent country among those at sea, or an absent loved-one among those left at home, provides the impetus and inspiration for fado's expression.

Heated controversy concerning fado's musicological predecessors runs parallel to the romantic "creation myth" above. Scholars Teófilo Braga (1905) and Aldaberto Alves (1989) assert fado's link to Arabic music. Following the nationalist strain in fado discourse, scholars such as Gonçalo Sampaio (1923) link fado to the rural traditions of Portugal's northern regions. Still others such as Mascarenhas Barreto (1970) argue that fado evolved from medieval troubadour songs that found their way to Portugal from Provence. ${ }^{15}$ Most recently, Brazilian ethnomusicologist José Ramos Tinhorão (1994) argues convincingly for fado's Afro-Brazilian roots. ${ }^{16}$ Tinhorão traces fado's early dance component to the Congolese lundum brought from Africa to Northeastern Brazil with the African slaves and from Rio de Janeiro to Portugal with the Portuguese Court in $1821 .^{17}$

Through the inclusion of "O Marujo," an African fadista, the exhibit "cites" these debates, all the while keeping fado history within the limits of a distinctly national timeline. By naming the exhibit's initial chronological unit as "Severa's Time" and not, for example "Fado's 1820 Journey from Brazil," the exhibit places fado in Portugal's arsenal of cultural heritage products. Following the loss of the African colonies in 1974, and a depletion of Portugal's identifying "wealth of possessions", fado becomes framed within the L94 exhibit as a distinctly indigenous treasure. MNE curators have, in the words of Lourenço, "designed, conceived, invented and given Portugal a future" not by drawing on the "outside", but by "drawing on themselves."

\section{EMBODIED SPECTATORSHIP}

MNE's complex deployment of sound in two exhibit stations provided the museumgoer with a rare experience of embodied spectatorship. The stations, entitled "Taberna" (The Tavern) and Amália, exemplify what Paul Stoller terms 'sensuous scholarship,'- “an attempt to reawaken profoundly the scholar's body by demonstrating how the fusion of the intelligible and the sensible can be applied to scholarly practices and representations." It is particularly important in anthropology, he argues, "to incorporate into ethnographic works the sensuous body, its smells, tastes, textures and sensations" in order to challenge the Eurocentric and phalocentric positioning of the body as a text to be read and analyzed (1997, $\mathrm{xv})$. 
MNE curators tacked back and forth between analytical representation of fado's social and corporeal body and sensuous engagement of both the ethnographic object and the museum audience. Following "Do Tempo da Severa," the exhibit presents several chronologically ordered displays. Knives, fado tattoos, kitschy liquor bottles in the shape of guitars, video monitors of lit cigarettes revealed fado's early twentieth century social setting where musicianship mingled with criminality. The exhibit also portrayed fado's entry into mass media - radio, film and national theater. A display of Spanish guitars, guitarras portuguesas and concertinas depicted the evolution of fado instrumentation and its later journey through Portuguese rurality. Curator Pais de Brito described these sections as having "an analytical register," a "cerebral, intellectual, informative" quality designed to "draw the viewer's attention to detail" (Brito 2000). Although these stations often included soundtracks dramatizing fado's social settings, the fadista's body, pictured on posters, playbills and medical documents, presented itself as an artifact to be "read and analyzed." It was not until the sections entitled "Taberna" and "Amália," that museum-goers experienced embodied spectatorship and emotional engagement.

In the "Taberna" section, the museum-goer is confronted by several small stools and a marble table oriented around a blank screen. The configuration of the space invites the visitor, not to apprehend these objects as artifacts, but to treat the stools and table as utilitarian objects within an experiential installation. We are clearly meant to sit down on the stools and look up at the screen as if patrons at a casa do fado. When I first attended the exhibit, my friend and I indeed sat down on the stools and waited for the screen animation. After a few moments, the screen lit up with moving images. There was no accompanying sound. It seemed to be a silent film. ${ }^{18}$ We sat and watched transfixed by the images of older fadistas dressed in black singing in a café we thought we recognized. We saw tables and chairs similar to the ones we were sitting in, food and drink reminiscent of Godinho's "codcakes" and "cups of white wine" enjoyed by a bustling group of fado aficionados. The camera closed in on the expressive face of one fadista-I noticed a filling in her tooth as her mouth widened to reach what I imagined was a high note. I wondered if the film was in slow motion-the absence of musical sound made the images languorous and surreal.

The silencing of the videoed fadista draws the viewer's attention not only to the physical surroundings of the tavern, but to the performer's body-her clothes, her face, and her movements. Fado's gestural vocabulary, when presented in silence, seemed dancerlythe backwardly tilted head, the knit brow, the tightly clenched hands, the open mouth. The Taberna's sound game provided an almost tactile experience of the performer's body and the corporeal markers of vocal expression. Like Stoller's call for the sensual engagement of ethnographic objects, this 1993 documentary footage of a fado tavern near Bairro Alto depicted the body, not as a text to be read, but as a dynamic locus of physical and emotional expression.

The aural game played by the video amounted to sensorial teasing, a point of crisis, where the viewer responds by craving musicality. I would also argue that this suspension of aural satisfaction mirrors the structure of fado's vocal stylistics. Traditional fado vocality enraptures listeners due in large part to impassioned melismatic phrasing. Fado singers typically extend words' beginning vowel sounds into moments of prolonged vocal improvisation, where a musical resolution is slow in coming and audiences are left hanging, waiting for closure in the full annunciation of the the word at the melisma's terminus. This manipulation of vocal "suspension" produces a dramatic tension within the body of the listener and constitutes the emotional locus of fado pathos and passion (Branco 2002). The Taberna's musicless fado film, produces a similar effect; the audience is "suspended", waiting anxiously for closure in the experience of fado's musical articulation. Sitting on bar stools, watching an impassioned singer mime fado vocality creates an intense thirst for 
sounded melody. Like fado's vocal melisma that builds tension and emotion through the skillful postponement of tonal resolution, MNE visitors are made to wait for aural satisfaction in the exhibit climax.

\section{ExhiBition ClimaX: Amália SINGS With “ABANDON”}

The hunger for musical sound created in Taberna is satiated in the "Amália" station, where fado's most famous voice animates the exhibit terminus. With "Amália," MNE curators created a "performative nucleus," an experience of fado's "artistic" voice from within the "sensual universe of emotion" (Brito 2000). In the most costly exhibit section, sound engineers constructed a hermetically sealed auditory space into which museum guards escorted small groups of visitors. The pitch black room, like a large sensory deprivation tank, was designed to contain sound, preventing visitors, standing even a meter away, from discerning what went on inside (Brito 2000).

Led down a long empty corridor, viewers entered a small door and felt their way toward seats. The door closed quietly and the intimate group of viewers was left alone in silence and darkness. Suddenly into the hushed atmosphere, the voice of Amália Rodrigues, fado's grand diva, burst forth. Lilting her way through subtle passages, Amália sang as if weeping. Muted phrasing gave way to bursts of throaty glissando as Amália breathed life into the poetry of David Mourão Ferreira's fado, "Abandono" (Abandon). Intense sound flooded the room in forceful waves. Encountering fado's musical voice, at long last, like touching raw expression itself, satisfied the craving produced by the Taberna's silent song.

Enormous slides of Amália, arms outstretched, accompanied the fado. These black and white photographs seemed to vibrate with sound, leaping off the wall toward the viewer with startling nearness. Amália's voice and image, inextricably linked, approached the viewer in claustrophobic close-ups. Sight, touted as "the only sense in which the advantage lies not in proximity but in distance" (Jonas 1954,517 ) paves the way for objectivity. With spatial distance, the objective viewer can apprehend "the thing as it is in itself as distinct from the thing as it affects me" (Jonas 1954, 515). In the Amália station, however, enormous images given voice became auditory phenomena, and maintaining spatial distance from the slides proved impossible. The enormity of the image coupled with the expressive power of Amália's voice brought countless viewers to tears (Brito 2000). ${ }^{19}$ Spectators, bombarded by sound and image, responded to fado's musical voice according to the indicators of physiological response- " "goose bumps on the flesh, trembling, the nervous system lodged within the body's fibers - this mysterious affect that some voices and songs produce" (Brito 2000). Amália's mellifluous image grown to gigantic proportions abolished the space for critical contemplation. Exhibit dramaturgy presented a crisis point in Taberna, where spectators sat down to witness a silent song. Amália's climax, however, conditioned the resolution of this crisis by delivering the voice and image of Portugal's notorious fado protagonist. Amália's station succeeded, not so much in catalyzing objective judgment, but in providing a cathartic moment of spectatorial pathos.

The hermetically sealed environment of the auditorium powerfully simulated the lyrical context of Abandono, a fado about political incarceration. Ferreira's Abandono, written in the final years of António Salazar's Estado Novo dictatorship, narrates a politically charged tale of absence and longing.

Por teu livre pensamento

Foram-te longe encerrar

Tão longe que o meu lamento

Não te consegue alcaņ̧ar; 
E apenas ouves o vento,

E apenas ouves o mar.

[For your free thought

They closed you up far away

So far that my lament

Can not reach you,

And you only hear the wind,

And you only hear the sea.]

At first glance this fado seems to contain the benign tropes of fado's lyrical expression under Salazar: love, lamentation, and maritime existence. And, indeed, it was this cursory gloss that kept the lyrics from being censored. ${ }^{20}$ If, however, one reads between the lines, as many were forced to do under Salazar, the man who was "closed up" for his "free thought" and "taken away in the middle of the night" "never again to see daylight" is construed not so much as a departing sailor, but as the victim of political persecution sent to prison by the sea. ${ }^{21}$ In the Amália station, the MNE visitor is trapped in a similar situation of darkness and confinement-a confinement which gives way to empathic sentience and embodied spectatorship. A confinement in which spectators recall fascism, one of fado's most recent political contexts, with unsettling experiential proximity.

Why include such a politically charged fado within an exhibit meant to celebrate Portugal's entry into European democracy? MNE curators featured Abandono, according to Brito, because the song reveals fado's social complexity and political ambiguity. Fado has been simultaneously stigmatized for its association with fascism, while also known for its circulation of anti-fascist sentiment. ${ }^{22}$ Abandono, interpreted as both a simple "lovesong" and a song about political imprisonment, boldly illustrates fado's double life. Harshly criticized by communist revolutionaries following the Estado Novo's fall in 1974, Amália Rodrigues, also contains this same duality. Amália has been both touted as the populist voice of Lisbon's working class while simultaneously critiqued as the mouthpiece for fascist cultural policies. $^{23}$

Simonetta Luz Afonso, Director of the Portuguese Institute of Museums and Administrator of the L94 Exhibitions Division, writes in 1994, "Propped up by uncomfortable political corsets, its spontaneity perverted by stagings of modern cultural tourism, fado seems today to be at a crossroads of impasse and interrogation." (1994, n.p.)

As Afonso attests, fascism's "political corseting" of fado occurred in the not too distant past, leaving fado in 1994 at a complex moment of disjuncture. In the Amália station, MNE boldly illustrated and indeed "interrogated" fado's implication in fascist history-a complex subject that many post-revolutionary intellectuals "want to distance themselves from" (Brito 2000). MNE's celebration of Portuguese cultural patrimony, therefore, should not be read as idle festivity or simple national showcasing. In its moment of vocal climax, the L94 exhibit exposed fado's transformation as a complex historical process that has involved "perversion" and "discomfort." The Amália station underscores fado's protean adaptation to dramatically changed political circumstance. Reminding museumgoers of fado's tumultuous journey through colonial entrenchment and release, fascism's rise and fall, revolution, communism, and now democracy, Amália's throaty voice intones a politics of polyphony and perseverance. 
CONCLUSION: FADO's SCHOLARLy Dignification

The promiscuous blending of quantitative data with qualitative data, historical documents with video footage, sights with sounds, spoke not only to the exhibit's multisensorial approach, but also to the social scientific methods that drove the curatorial process. Two years of intensive research preceded the mounting of MNE's fado exhibit. Ruben de Carvalho, president of L94's Popular Music Division explains:

We wanted to take advantage of the opportunity offered by the European Capital of Culture to accomplish a project which had, from our point of view, never in fact been done: to study fado as the popular song of Lisbon ... Due to its density and history, fado deserved above all else, to be studied. And clearly studying fado grants it dignity, as a form of popular culture. (1994a; 119, 124 bold type in original)

To this end, several teams of researchers led by Carvalho, MNE Director Joaquim Pais de Brito, ethnomusicologist Salwa Castelo-Branco and sociologist António Firmino Costa formed the nucleus of what became known as L94's Projecto Fado. These teams performed exhaustive archival research and ethnographic fieldwork. They conducted and transcribed interviews with fado musicians and audiences, collected fado artifacts from historical archives, local institutes and private residences, photographed fado performances and compiled fado lyrics. This research formed the core both of the exhibit and the companion catalogue that featured lengthy articles on fado instrumentation, ethnographic case studies and musician biographies.

The dignification of fado through systematic study not only produced a cutting edge exhibit, but also acted as a corrective to the "internal paralysis" which has characterized the discipline of anthropology throughout much of twentieth century Portugal (Cabral 1991, 15) ${ }^{24}$ Following a period of enforced isolation from European knowledge production within the social sciences, Portuguese anthropologists in the Projecto Fado led a team of investigators to the forefront of interdisciplinary research and innovative museological practice. This process, catalyzed by the European City of Culture festival, not only continued the amplification of fado's national voice, but also marked the broadening of Portuguese anthropological epistemology. The fado exhibit, as both product and process, therefore, greased the wheels of national unification with Europe, by projecting Portugal's social scientific voice into the international auditorium of critical anthropological discourse.

The exhibit incorporates post-structuralist critique of anthropology into its curatorial methods and museum display in several important ways. First, Johannes Fabian has critiqued anthropological discourse for it's "denial of coevalness" arguing that ethnographers have represented themselves in the "here and now" while their objects of study exist in the "there and then" (Fabian 1983). ${ }^{25}$ Ethnographic research, whether processed into written or museological "narratives," has traditionally been represented as stagnant, unchanging, and "synchronous" (Fabian 1983, 121). Fado: Vozes e Sombras combined chronological elaborations of fado's dynamic history with a set of "experiential stations" where museum visitors encountered fado on different sensorial levels. This organizational dramaturgy challenges the ethnographic museum's history of visualist and synchronous logic by including chronologically ordered displays and auditory stagings of fado that, in effect, simulate the ethnographers' experience of coevalness in the field. As Ruben de Carvalho underscores, "Fado . . . is alive. It is sung, it is played, everyday in numerous locales. It is surrounded by audiences, amateurs, professionals, commercial and technical structures" (1994a, 124). And this is readily apparent in the exhibit, a celebration of both diachronic change and contemporaneity. 
Secondly, unlike traditional ethnographic displays predicated on the distance (either geographical or social) between anthropological observer and observed, the ethos of the exhibit was one of complicity and sharing. Unlike many ethnographers of the past who have "ripped off the data and run" (Conquergood 1985), Projecto Fado investigators committed to extended periods of field work and the development of ongoing relationships with fado informants. Many of these ethnographers were both fado performers and "native anthropologists," answering recent calls in feminist anthropology and performance studies scholarship for more participatory and enmeshed relationships between ethnographic subject and object (Conquergood 1991, Abu-Lughod 1991 Visweswaran 1994, Narayan 1993). Fado musicians also knowingly and willingly participated in the act of data and object collection, many later attending the exhibit and maintaining correspondence with the exhibit curators (Brito 2000). The implied audience for this exhibit was as much an emic community of fado artists and aficionados as an etic community of unknowing observers. Just as fado's performance history interweaves the oppositional voices of the working class and the aristocracy, so too does the exhibit speak to anthropological subject and object, insider and outsider. The fado exhibit turned the Museu Nacional de Etnologia into a "contact zone" (Clifford 1997), where fado artifacts were not so much displays of "exotic specimens," "function[ing] as open books to provide 'object lessons"" (Dias 1994, 165), as they were national relics for the collective contemplation and indeed celebration of fado's history of protean transformation.

Thirdly, the leaders of the Projecto Fado intended the exhibit to act as a catalyst for further research. The Projecto Fado produced a textual counterpart to the exhibit, not only in the form of the exhibit catalogue, but also two volumes of fado scholarship, and the publication of several classic texts on fado long out-of-print. ${ }^{26}$ The exhibit framed itself not as the "final word" on fado, but rather as a progenitor for future voices in a scholarly dialogue about fado. The implicit heurism of the exhibit catalyzed other exhibits. Not only did Fado: Vozes e Sombras travel to two major museums in Rio de Janeiro following L94 with another visit to Paris scheduled for 2002, it also influenced the founding of the museum Casa do Fado e da Guitarra Portuguesa (Fado House and Portuguese Guitar Museum) (Brito 2000). ${ }^{27}$ The exhibit was, in this sense, not only reflective but generative of fado's social and scholarly voices.

MNE curators researched and displayed 150 years of fado history, transforming the traditionally silent space of the museum into a theater of sounds where animism meets artifact. Fado: Vozes e Sombras challenged museum-goers to decipher ambient audioscapes as they gazed at material documents, melding sights and sounds into dramatized mise-enscènes of fado's historical origins and contemporary life. MNE pedagogy challenged viewers to think and feel their way through exhibit stations, demanding both critical cognition and emotional engagement. The exhibit closed with an image of a blind fadista, an ever-present archetype within the fado pantheon of highly visible national talent. The anonymity of this blind figure, in stark contrast to the cult of personality portrayal of Severa, Alfredo Marceneiro and Amália, comments obliquely on the sense of sight as an unnecessary ingredient in the projection and reception of musical vocality. As the blind musician escorts the viewer to illuminated exit signs, we are left to ponder yet another sensory riddle. If "the inclusion of the sense of hearing within anthropological practice leads to a radical shift in the way external reality has been considered" (Dias 1994), then perhaps blindness is the ideal state in which to apprehend auditory "objects of ethnography." 
NOTES

Earlier versions of this paper were presented at the Association for Theater in Higher Education conference in 1998 and in 2000 at American Portuguese Studies Association conference. I would like to thank Joaquim Pais de Brito for sharing his insights with me. I also thank António Joel and Tim Raphael for their careful readings of this essay. Any errors are my own.

${ }^{1}$ Unless otherwise noted, all translations are my own.

${ }^{2}$ In a study of the relationship between anthropology and museums, Robert González, Laura Nader and Jay Ou argue that, "museums have been critical sites of anthroplogical research since the modern formation of the discipline in the nineteenth century." The authors assert that late nineteenth century anthropologists used museums to provide visual support for social evolutionary theories of human development and to legitimize "ongoing colonial enterprises and civilising missions" $(2001,106)$.

${ }^{3}$ Museologist Nélia Dias terms these two modes of display "typological" and "geographical" systems of classification" (1994).

${ }^{4}$ For a study of L94's transformation of Lisbon's urban space, see Holton 1998

5 Defining identity as a wealth of possessions sheds light on Portugal's postrevolutionary identity crisis, where, following the loss of the African colonies"geographical possessions" upon which Portugal's imperial image had rested for centuries--Portugal has had to explore and promote other indigenous treasures in order to reconfigure a new sense of national identity.

${ }^{6}$ The street vendor's cry, or pregão, has become a common trope in fado lyrics concerning Lisbon's historic neighborhoods of Alfama and Mouraria. In "Ai Mouraria," a fado by Amadeu do Vale and Frederico Valério, for example, pregões are featured elements in the chorus describing the mythologized space of Mouraria:
Ai Mouraria
Dos rouxinois nos beirais
Dos vestidos cor-de-rosa
Dos pregões tradicionais
(Roseiro 1992, 18)
[Oh Mouraria
With nightingales in the eves
With pink dresses
With traditional street vendors cries]

Street vendors, still today, pass through neighborhoods announcing products they have for sale. These utterances feature cadences particular to the vendor's vocal personality. In the course of field work I conducted in 1994-96 with revivalist folklore groups in Portugal's Estremadura region, I discovered that many ranchos folclóricos perform "pregões" as part of their musical repertoire.

${ }^{7}$ MNE Director Joaquim Pais de Brito consistently referred to the exhibit soundscapes as "sculptural" (2000).

${ }^{8}$ Scholars debate the exact date of fado's first appearance in Lisbon. Pinto de Carvalho (1903) asserts that fado was only performed after 1840. Miguel Queirol (1901) dates fado's first appearance in the 1820 s. 
${ }^{9}$ Brito cites several events such as bullfights, running of the bulls, balloon flights, and acrobatic performances, where the classes had an opportunity to mix and where the aristocracy experienced a "rupture of . . . their standards of reference" (1994c, 20)

${ }^{10}$ See Sucena 1992 for a detailed historical portrait of Severa, including the many fado lyrics which narrate Severa's colorful life.

${ }^{11}$ These documents are essential in verifying the existence of Severa, who for many decades was considered merely a " fictional character" within the oral lore of fado (Sucena 1992, 19)

${ }^{12}$ Kirshenblatt-Gimblett's argument speaks not only of a poetics of detachment, but also of alienation, in Brecht's sense of the word. Brecht's famous formulation of the spectator leaning back in his chair smoking a cigar as the only posture in which one can engage the mind in a critical consumption of theatrical spectacle speaks of this physical and emotional detachment needed not only in creating but appreciating the "alienation effect."

${ }^{13}$ The dynamic described by Lourenço is articulated by many other Portuguese scholars from varying disciplines. Historian António José Saraiva argues, for example, that "the Portuguese have not shown a very clear consciousness of the border which separates our culture from foreign cultures. . . The line separating us from others becomes nuanced, hazy, blurry--enabling a certain promiscuity with exterior cultures" $(1994,84)$.

${ }^{14}$ Many journalists complained that the L94 festival-in its segmented program organization and execution--- produced a "balkanization" of Portuguese culture. Fado, the sole unifying element featured across festival divisions such as Dance, Popular Music, Theater, and Urban Animation, was repeatedly deemed the "ex libris" of L94.

${ }^{15}$ The first half of this paragraph draws on Joaquim Pais de Brito's (1994b) succinct account of these debates

${ }^{16}$ Earlier scholars, such as Luís Moita (1936), also defended this idea.

${ }^{17}$ The Portuguese court fled Portugal in 1808 to escape the French invasions and stayed in Rio de Janeiro until 1821, when they returned to Lisbon.

${ }^{18}$ I learned later through discussions with Joaquim Pais de Brito that this film did indeed have a soundtrack. However, the sound featured only ambient noises recorded in a local casa do fado-plates banging against tables and glasses clinking. Both times I attended the exhibit, I failed to perceive these sounds, later writing about the film as "silent" in field notes. I believe my misperception was directly related to the dramatic absense of musical sound. Watching a vocalist in performance, my ear was prepared for one genre of sound

${ }^{19}$ Brito reported that many people emerged from the Amália station visibly moved or weeping. Brito was particularly struck by a group of German sound engineers whose popular musical traditions, he reported, do not feature "a strong history of melancholy ballads", but who were nonetheless deeply moved by the exhibit, exiting the Amália station "in tears" (2000).

${ }^{20}$ Amália also reported that she thought Abandono was merely "a lovesong" (Brito 2000).

${ }^{21}$ The identity of this prison, though never named in Ferreira's fado, could be readily interpreted as one of Salazar's seaside jails-Caxias, Peniche or Tarrafal-- infamous locales of political torture and incarceration which have found their way into countless postrevolutionary novels and films, notably António Lobo Antunes' A Ordem Natural das Coisas and Maria de Medeiros feature film, Capitães de Abril.

${ }^{22}$ See, for example, "Chapter 3" in Costa and Guerreiro 1984.

${ }^{23}$ Cited in her biography, Amália rages against such accusations stating, "How did [the revolutionaries] know I was against them when the revolution occurred? They don't know anything! [After the $25^{\text {th }}$ of April] People took over the newspapers and not a word was written about me. People took over the radio and my records were never played. People took 
over the television and I couldn't appear. But they couldn't turn the public against me. . . . The public never abandoned me. But why did this happen? Why all of this hatred? I was never the Minister of anything. I've never given an order in my life." $(1987,182)$.

${ }^{24}$ In his study of Portuguese anthropology, João Pina Cabral affirms in 1991that "Portuguese anthropology finds itself in the midst of an unprecedented period of development" (1991, 11). This flourishing of the Portuguese social sciences occurs, according to Cabral, after a long period of lackluster and anachronistic research produced during the dictatorship (1926-74), when anthropology was harnessed to official corporativist and nationalist ideologies. Corporativism and the existence of a relatively small community of anthropologists yielded "little creative dialogue and professional competition" which led to the "repression of innovation and preservation of antiquated scientific theories and methods. The isolation which permite[d] these anachronisms [was] created through elaborate processes of academic exclusion that, while well established within Portuguese universities, were reinforced during Salazar's dictatorial regime" $(1991,13)$.

${ }^{25}$ Fabian elaborates this disjuncture between method and representation, "Productive empirical research, we hold, is possible only when the researcher and the researched share Time. . . . Yet the discourse that pretends to interpret, analyze, and communicate ethnographic knowledge ... is pronounced from a 'distance,' that is, from a position which denies coevalness to the object of inquiry" $(1983,71)$.

${ }^{26}$ The primary texts reprinted for L94 were, Pinto de Carvalho's $A$ História do Fado, Alberto Pimentel's A Triste Canção do Sul, Luís Moita's $O$ Fado Can ção dos Vencidos, José Maciel Ribeiro Fortes' O Fado and António Osório's A Mitologia Fadista (Carvalho 1994a, 1994b).

27 For more about this museum, see Alves 2000, or visit the website www.ebahl.pt/casadofado.

\section{WORKS CITED}

Abu-Lughod, Lila. 1991. "Writing Against Culture." Recapturing Anthropology. Ed. Richard Fox. Santa Fe: SAR P.

Afonso, Simonetta Luz. "Preface." Fado: Vozes e Sombras. Lisbon: Sociedade Lisboa 94, n.p.

Alves, Aldaberto. 1989. Arabesco: Da Música Arabe e da Música Portuguesa. Lisbon: Assírio \& Alvim.

Alves, Jorge Lima. 2000. “António Chainho: Entrevista.” Expresso Revista. 1 December, 103-10.

Bachelard, Gaston. 1994[1958]. The Poetics of Space. Trans. Maria Jolas. Boston: Beacon $P$.

Barreto, Mascarenhas. n.d. [1970]. Fado, Origins Líricas e Motiva ̧ão Poética. Lisbon: Editorial Aster Lda.

Bourdieu, Pierre. 1984. Distinction: A Social Critique of the Judgement of Taste. Trans. Richard Nice. Cambridge, MA: Harvard UP.

Braga, Teófilo. 1905. História da Poesia Popular Portuguesa. Lisbon: Manuel Gomes.

Branco, Salwa Castelo. 2002. "Portuguese Fado: The Performance of Emotion." Invited Lecture given at Rutgers University-Newark, April 29.

Brito, Joaquim Pais de. 1994a. “Apresenta̧ão." Fado: Vozes e Sombras. Lisbon: Sociedade Lisboa 94, 13-14.

1994b. “Catálogo.” Fado: Vozes e Sombras. Lisbon: Sociedade Lisboa 94, 177-242 
1994c. "Fado Vozes e Sombras." Fado Vozes e Sombras, Lisbon: Sociedade Lisboa

94, 15-36.

2000. Telephone Interview with Author. Audio Recording. December 16.

Cabral, João de Pina. 1991. Os Contextos de Antropologia. Lisbon: Difel.

Carvalho, Pinto de. 1984 [1903]. História do Fado. $2^{\text {nd }}$. Edition. Lisbon: Dom Quixote.

Carvalho, Rubem de. 1994a. As Músicas do Fado. Porto: Campo das Letras.

1994b. "Relatório Final de Lisboa 94: Música Popular." Unpublished manuscript.

Certeau, Michel de. 1984. The Practice of Everyday Life. Berkeley: U of California P.

Clifford, James. 1988. The Predicament of Culture: Twentieth Century Ethnography, Literature and Art. Cambridge: Harvard UP.

1997. Routes: Travel and Translation in the Late Twentieth Century. Cambridge, MA: Harvard UP.

Conquergood, Dwight. 1985. "Performing as a Moral Act: Ethical Dimensions of the Ethnography of Performance." Literature in Performance 5, 1-13.

- 1991. "Rethinking Ethnography: Towards a Critical Cultural Politics. Communication Monographs 58, 179-94.

Constâncio, Vítor. 1994. "Lisbon, Cultural Capital of Europe: A Meeting Point of Cultures." Lisbon 94 Official Programme. Lisbon: Sociedade Lisboa 94.

Costa, António Firmino da e Maria das Dores Guerreiro. 1984. O Trágico e o Contraste. $O$ Fado no Bairro da Alfama. Lisboa: Dom Quixote.

Costa, Júlio de Sousa e. 1939. Severa. Lisbon: Livraria Bertrand.

Dias, Nélia. 1994. "Looking at Objects: Memory, Knowledge in Nineteenth-Century Ethnographic Displays." Travellers' Tales: Narratives of Home and Displacement. Eds. George Robertson et.al. London: Routledge, 164-76.

Fabian, Johannes. 1983. Time and the Other: How Anthropology Makes its Object. New York: Columbia UP.

Godinho, Sérgio. 1993. “Apontamentos Vertentes de uma Canção de Lisboa." O Mistério de Lisboa. Lisbon: Relógio D’Agua, 27-32.

González, Roberto J., Laura Nader and C. Jay Ou. 2001. "Towards an Ethnography of Museums: Science, Technology and Us." Academic Anthropology and the Museum: Back to the Future. Ed. Mary Bouquet. New York: Berghahn Books, 106-16.

Holton, Kimberly DaCosta. 1998. "Dressing for Success: Lisbon as European Cultural Capital." Journal of American Folklore 111(440): 173-96.

Jonas, Hans. 1954. "The Nobility of Sight." Philosophy and Phenomenology Research 14: 507-19.

Kirshenblatt-Gimblett, Barbara. 1991. "Objects of Ethnography." Exhibiting Cultures: The Poetics and Politics of Museum Display. Eds. Ivan Karp and Steven D. Lavine. Washington D.C.: Smithsonian Institute P, 386-443.

Loureço, Eduardo. 1998. We the Future. Lisbon: Assírio \& Alvim.

Moita, Luís. 1936. O Fado, Canşão de Vencidos. Oito Palestras na Emissora Nacional. Lisboa.

Narayan, Kirin. 1993. "How Native is a "Native" Anthropologist?" American Anthropologist 95 (3): 671-86.

Official Journal of the European Community. 1985. Resolution of the Ministers Responsible for Cultural Affairs (Resolution 85C, 153/02). June 22.

Quierol, Miguel. 1901. O Popular. 7 and 8 of April.

Roseiro, António. 1992. Fados Caņ̧ões: Compêndio de Cantigas. Gráfica Povoense.

Sampaio, Goncalo. 1923. "As Origens do Fado." A Aguia 9,10 (March, April), 131-33.

Shepard, R. 1986. "Music Consumption and Cultural Self-Identities: Some Theoretical and Methodological Reflections." Media, Culture and Society 8, 305-30. 
Santos, Vítor Pavão dos. 1987. Amália: Uma Biografia. Lisbon: Contexto.

Saraiva, António José. 1994. A Cultura em Portugal, Teoria e História Vol 1, Introdução Geral à Cultura Portuguesa. Lisbon: Gradiva.

Silver, Jeremy. 1990. "'Astonished and Somewhat Terrified': The Preservation and Development of Aural Culture." The Museum Time-Machine. Ed. Robert Lumley. London: Routledge, 170-95.

Stoller, Paul. 1997. Sensous Scholarship. Philadelphia: U of Pennsylvania P.

Sucena, Eduardo. 1992. Lisboa: O Fado e os Fadistas. Lisbon: Vega.

Tinhorão, José Ramos. 1994. Fado: Dan ̧a do Brasil, Cantar de Lisboa. Lisbon: Caminho.

Visweswaran, Kamala. 1994. Fictions of Feminist Ethnography. Minneapolis: U of Minnesota P. 
http://www.jstor.org

\title{
LINKED CITATIONS \\ - Page 1 of 1 -
}

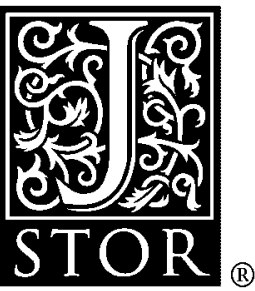

You have printed the following article:

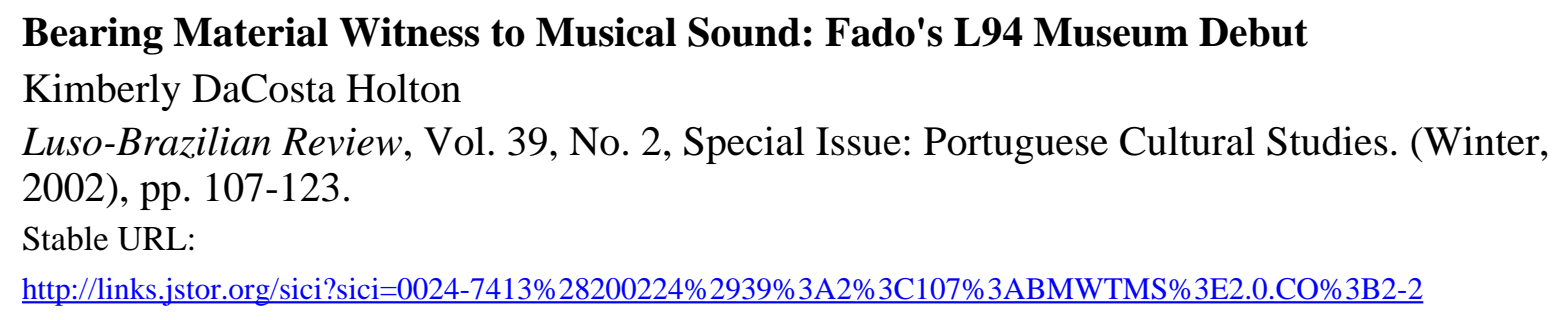

This article references the following linked citations. If you are trying to access articles from an off-campus location, you may be required to first logon via your library web site to access JSTOR. Please visit your library's website or contact a librarian to learn about options for remote access to JSTOR.

\section{Works Cited}

\author{
Dressing for Success: Lisbon as European Cultural Capital \\ Kimberly DaCosta Holton \\ The Journal of American Folklore, Vol. 111, No. 440, In Modern Dress: Costuming the European \\ Social Body, 17th-20th Centuries. (Spring, 1998), pp. 173-196. \\ Stable URL: \\ http://links.jstor.org/sici?sici=0021-8715\%28199821\%29111\%3A440\%3C173\%3ADFSLAE\%3E2.0.CO\%3B2-B
}

\author{
How Native Is a "Native" Anthropologist? \\ Kirin Narayan \\ American Anthropologist, New Series, Vol. 95, No. 3. (Sep., 1993), pp. 671-686. \\ Stable URL: \\ http://links.jstor.org/sici?sici=0002-7294\%28199309\%292\%3A95\%3A3\%3C671\%3AHNIA\%22A\%3E2.0.CO\%3B2-Z
}

